\title{
数値計算による不飽和浸透水槽における 分散長の評価 \\ EVALUATION OF DISPERSIVITY UNDER UNSATURATED CONDITION BY NUMERICAL SIMULATION OF TRACER TEST IN THE SEEPAGE TANK
}

\author{
中川 啓 1 ・齋藤雅彦 2 ・朝倉 宏 3 \\ Kei NAKAGAWA, Masahiko SAITO and Hiroshi ASAKURA \\ 1正会員 博(工) 長崎大学教授 大学院水产・環境科学総合研究科(广852-8521 長崎市文教町1-14) \\ 2 正会員 博(工) 神戸大学助教 自然科学系先端融合研究環 重点研究部( ₹ 657-8501神戸市灘区六甲台町1-1) \\ 3博(工) 長崎大学准教授 大学院水産・環境科学総合研究科(广852-8521 長崎市文教町1-14)
}

\begin{abstract}
It is important to apply proper dispersivity in unsaturated condition when solute transport near the soil surface is assessed. However data on unsaturated dispersivity are limited because dispersion in unsaturated condition is more complicated than in saturated condition. In the previous study, we tried to evaluate unsaturated-dispersivity by tracer experiment in the laboratory seepage tank. However, it was difficult to investigate clear results because observed values were scattered. In this study, numerical tracer simulation was conducted under unsaturated water flow condition. The numerical tracer simulation results were confirmed that longitudinal and transverse dispersivities have dependency on soil water content. When the water content is lowered, dispersivity becomes larger. The ratio of transverse dispersivity to longitudinal dispersivity was in the range of 1/1000-1/6000. Numerical results showed that longitudinal dispersivity may have almost constant value in the small scale as seepage flow tank used in this study.
\end{abstract}

Key Words : dispersivity, unsaturated condition, numerical-tracer experiment, convectivedispersive equation, breakthrough curve

\section{1. はじめに}

土壤中や地下水中における物質輸送を規定する重要な パラメータの一つに分散長がある. 特に, 農用地におけ る肥料成分の移動や市街地における污染物質の移動など の地表面近傍での物質輸送では, 不飽和条件下での分散 長の評価が重要となる ${ }^{1)}$. しかし，飽和条件下における 分散長の評価に比べ，土畩水分量に依存するなど2)，そ のメカニズムが複雑であるため，十分に検討されてきた とは言えない. 著者らは, 水平浸透水槽を用いて, 水平 な地下水流机とその直上をひとまとめにした巨視的な不 飽和領域において，任意の水頭勾配および体積含水率の 条件下で，トレーサ一試験を行い，トレーサー投入点下 流側の各点で得られた破過曲線から縦および横方向の分 散長を評価することを試みている3)。そ結果, 縦方向 および横方向分散長の体積含水率依存性と，体積含水率
が低下寸ると縦方向分散長が大きくなる傾向にあること を確認した. また縦方向分散長が流下距離に応じて大き くなる傾向があることを示した．しかし，実駼結果が大 きくばらついていたことや，限られた実験ケースにより 評価された結果であった. そこで本研究では, 文献3)に おける実験結果を補完することや結果の検証を目的とし て, 実験と同様の不飽和条件下における分散長の評価に ついて, 数值実験的に検討した. 寸なわち, 水平浸透水 槽における3 次元数值解析の結果を, 鉛直方向に断面平 均して，体積含水率と分散長を評価した.

\section{2. 室内実験の概要 ${ }^{3)}$}

実験装置の概要を図-1に示す，浸透層部分は，縦80 $\mathrm{cm}$, 横50 cm, 高さ $10 \mathrm{~cm}$ とし, 浸透層内には平均粒径 


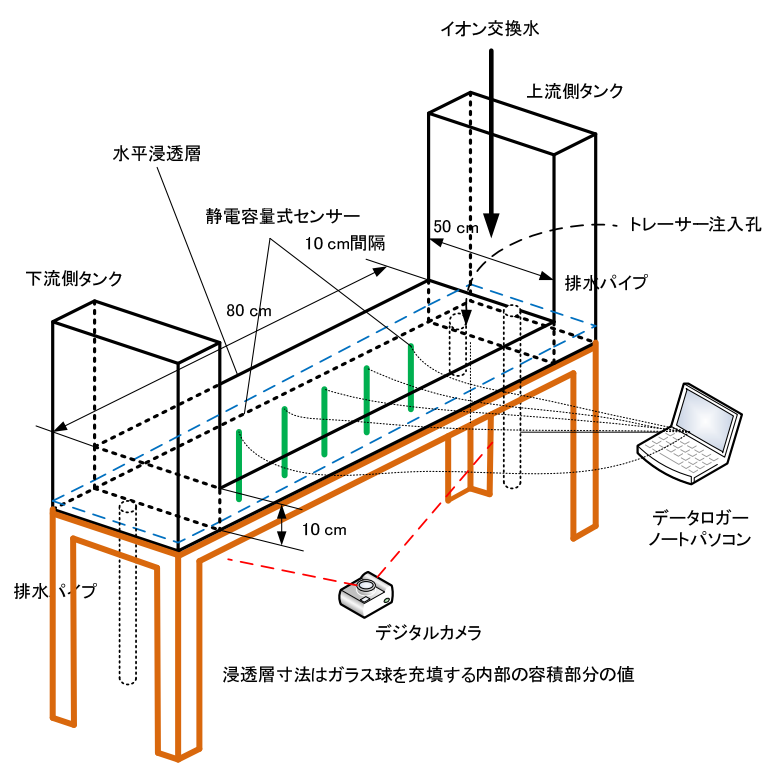

図-1＼cjkstart実験装置の概要 ${ }^{3)}$

$1.2 \mathrm{~mm}$ のガラスビーズを, 密度 $1.58 \mathrm{~g} \mathrm{~cm}^{-3}$ となるように 充填した。浸透層部分の両側にはスクリーンを介してタ ンクを接続し，それぞれにオーバーフローにより水位を 固定するための任意の高さに設定できる排水パイプを設 けた. 上流側のタンクには，イオン交換水を注水するよ うにした．浸透層の上蓋には，上流側に注入孔を設け， その位置から下流側に向かって上蓋中央部に，10 cmご とに5 点観測点を設け (No.1〜 5), 静電容量式の土㖶水 分・電気伝導度計を鉛直に挿入・固定できるようにした。 この静電容量式センサーは, 浸透層内の部分の長さが $6.7 \mathrm{~cm}$ で，水槽の鉛直方向 (深さ方向)の值の代表值を取 得できると考えた. トレーサー注入孔は，金網を巻いた 直径5 mmの多孔パイプとして, シリンジにより水槽上 面から下面まで一様にトレーサーが投入できるようにし た. 実験は以下の手順で行った. トレーサー注入孔から 塩化カリウムを $0.7 \mathrm{~g} \mathrm{l}^{-1}$ の濃度でシリンジを用いて60 ml を瞬間投入した．トレーサーの瞬間投入の後，各測定点 における土壤水分と電気伝導度を 1 分ごとに測定した.

\section{3. 数值計算モデル}

\section{(1) HYDRUS2D/3DIによる数值計算の概要}

本研究では，米国農務省塩類研究所において開発され た土中水分・溶質移動予測汎用プログラムである HYDRUS2D $/ 3 D^{4}$ をを用いて数值計算を実施した。本汎用 プログラムは，欧米を中心に農学分野で精力的に用いら れており，様々な現象への適用事例も多く広く用いられ ている. HYDRUS2D/3Dは，水の流れはRichards式，溶 質移動は移流分散方程式に基づき，それぞれガラーキン

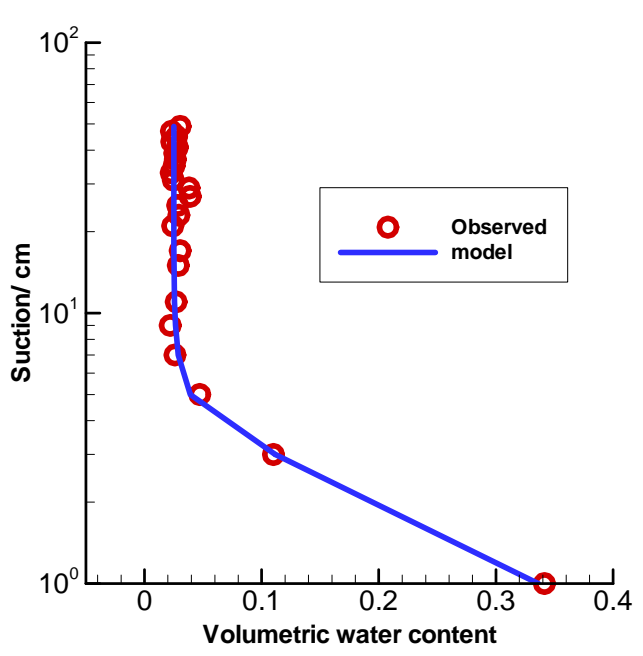

図-2 水分特性曲線（ $n=4.864, \theta_{\mathrm{s}}=0.341, \theta_{\mathrm{r}}=0.0249, \alpha=0.446 ）$

有限要素法によって計算される.

\section{（2）計算条件および計算に用いた諸条件}

実験における浸透水槽の横幅は50 cmであるが，計算 領域を節約するため30 cmとした。計算領域の幅を30 cm とすることは，実験結果および予備的な数值計算による と, トレーサーの横方向の拡がりに影響しない. 深さ方 向は10 cmを1 cm毎の11 レイヤーとした. 空間の離散化 は，ガラーキン有限要素法により，格子点間隔が $1 \mathrm{~cm} に$ なるように三角形要素で構成した，各レイヤー上の観測 点位置で濃度を求め, 全レイヤーの值を平均して, 観測 点の濃度 (断面平均濃度) とした.

初期条件は，後に示す実験・数值計算厅ースの水頭を 上下流に設定し，それ以外の領域は，下流側と同じ水頭 分布を与え, 浸透流を計算して得られた圧力水頭の定常 值を与えた. 濃度の初期条件は次のようにした. まず, 注入した瞬間のトレーサーの拡がりを実測したところ, 半径6 cmの円であった. この円に入る三角形要素に対し て，有効空隙率を40\%と仮定して実験時に注入した KCl の量 $42 \mathrm{mg}$ から濃度を計算すると, $0.95 \mathrm{~g} \mathrm{l}^{-1}$ となった. この濃度の $1 / 3$ そ内の三角形要素の接点上に与えた。 その結果, ほぼ同心円状の初期分布が得られており, こ れを濃度の初期分布とした。

境界条件は，上下流は圧力水頭について，固定水頭境 界で，濃度については，第3種の境界条件とした。その 他の面は圧力水頭および濃度について，フラックス無し の条件とした.

本研究では，飽和-不飽和浸透流解析を行うので，不 飽和パラメータが必要である.ここでは，van Genuchten のモデル（VGモデルとする）を適用し，カラムを，実 験に用いたガラス球で充填し，土柱法により排水試験デ 
表-1 実験・数値計算ケース

\begin{tabular}{cccccc}
\hline 水位 & $\mathrm{Ex} 1$ & $\mathrm{Ex} 2$ & $\mathrm{Ex} 3$ & $\mathrm{Ex} 4$ & $\operatorname{Ex} 5$ \\
\hline 上流側 & $3.7 \mathrm{~cm}$ & $5.3 \mathrm{~cm}$ & $6.9 \mathrm{~cm}$ & $8.5 \mathrm{~cm}$ & $11.0 \mathrm{~cm}$ \\
下流側 & $3.1 \mathrm{~cm}$ & $4.7 \mathrm{~cm}$ & $6.3 \mathrm{~cm}$ & $7.9 \mathrm{~cm}$ & $10.4 \mathrm{~cm}$ \\
\hline
\end{tabular}

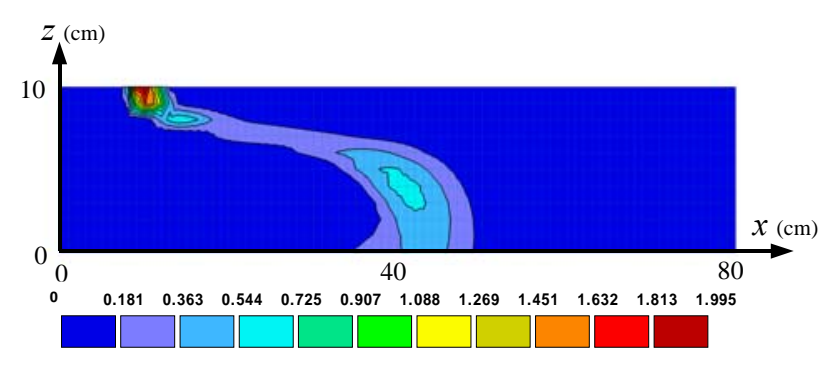

Concentration $C\left(\mathrm{~g} \mathrm{l}^{-1}\right)$
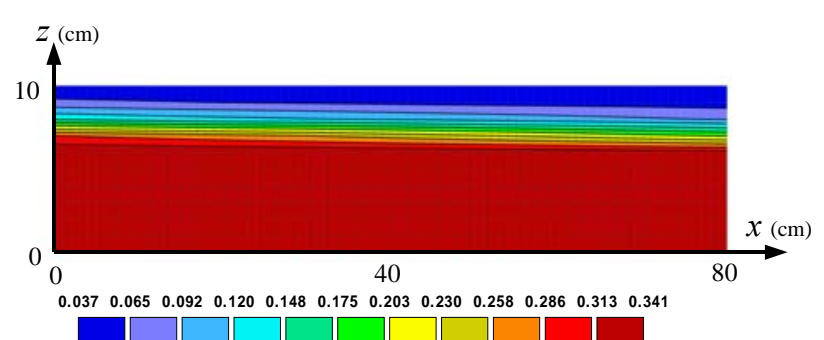

Volumetric water content

図-3 トレ一サ一輸送の数值計算結果例（左) 濃度分布, (右) 体積含水率分布 (Ex2, トレ一サ一注入 1008s 後)

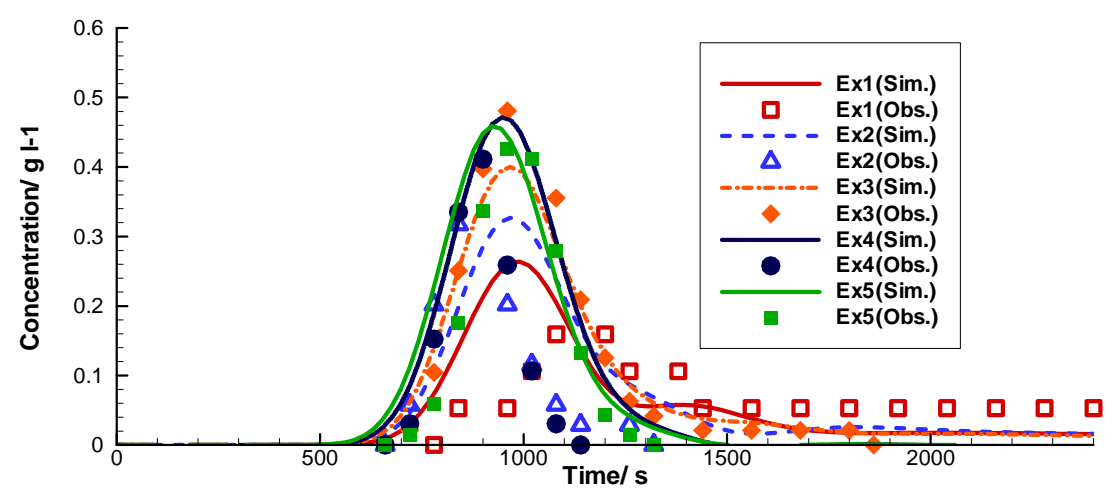

図-4 破過曲線の数值解と実測值の比較（観測点 No. 3)

一タを得て，非線形最小自乗法により，パラメータの同 定を行った. 得られたパラメータは, $n=4.864, \theta_{\mathrm{s}}=0.341$, $\theta_{\mathrm{r}}=0.0249, \alpha=0.446$ である. 図-2に得られた結果と同定し たパラメータによる水分特性曲線を示す. 用いたガラス 球は，平均粒径が比較的大きく，排水試験による特性曲 線は，困のような結果であった。飽和透水係数は，室内 試験により決定した值を基に，前報3)の実験結果を再現 できるように調整を行い決定し， $k_{\mathrm{s}}=1.56 \mathrm{~cm} / \mathrm{s}$ とた．ガ ラス球の微視的分散長は, 縦方向が $0.216 \mathrm{~cm}$, 横方向を

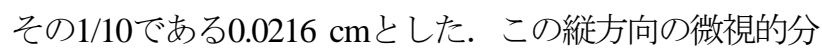
散長は，ガラス球の平均粒径1.2 mmとして, Bearの分散 係数に関する式 より算定した.

\section{（3）数値計算ケースと数値計算の妥当性}

ここでの数值計算ケースは，前報3の実験ケースにな らい，飽和から不飽和にかけて，5段階の水位で，上下 流の水頭差はいずれも0.6 cmとした．数值計算は，3600

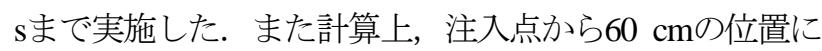
も観測点を設けた. 表-1に実験・数值計算ケースをまと めている.

図-3に数值計算結果の一例として，Ex2のトレーサー 注入1008 s後のプリュームの様子と体積含水率の分布を 示す．結果は，浸透水槽の中央を通る平面による断面図 として示す. 水槽下部の飽和帯において, トレーサーの
輸送が先行し，不飽和帯である上部で遅れていることが 明らかになった。 寸なわち，水分量の多い部分を選択的 に流下し，逆に水分量の少ない部分を迂回するように流 下することで，浸透層スケールで見た場合の巨視的分散 が見掛け上，大きくなると考えられる.このようなメカ ニズムにより，分散長の大きさは水分量に依存すると考 えられる.

図-4に，すべてのケースに対する観測点No.3における 破過曲線の実験結果 ${ }^{3}$ と鉛直方向に断面平均した数值計 算結果を比較して示す。なお観測点No.3は，トレーサー 注入点から30 cmの位置である. 全てにおいて適合性が 高いとはいえないが，破過曲線の形状やピークの值など， 数值計算結果は, 概小実験結果を再現しているといえ, 数值計算方法のほぼ妥当性が確認されたと考える.

\section{（4）数値計算結果から分散長の評価方法}

前報3) と同様に以下の様に考え，鉛直方向に断面平均 した数值計算結果から分散長の評価を行った. 平面2 次 元の物質輸送方程式は, 移流分散方程式で与えられる.

一定速度の流れ方向を $x$ 軸に一致させて，かつ対象とし ている物質が固相へ非吸着性であるとすれば，次式のよ うになる6).

$$
\frac{\partial \theta C}{\partial t}+u \frac{\partial \theta C}{\partial x}=D_{\mathrm{L}} \frac{\partial^{2} \theta C}{\partial x^{2}}+D_{\mathrm{T}} \frac{\partial^{2} \theta C}{\partial y^{2}}
$$




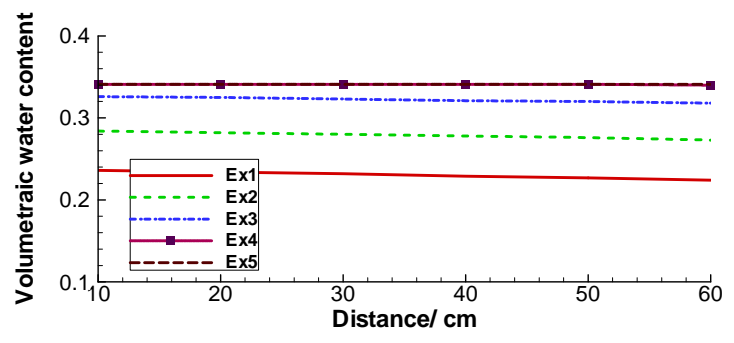

図-5 平均体積含水率の分布

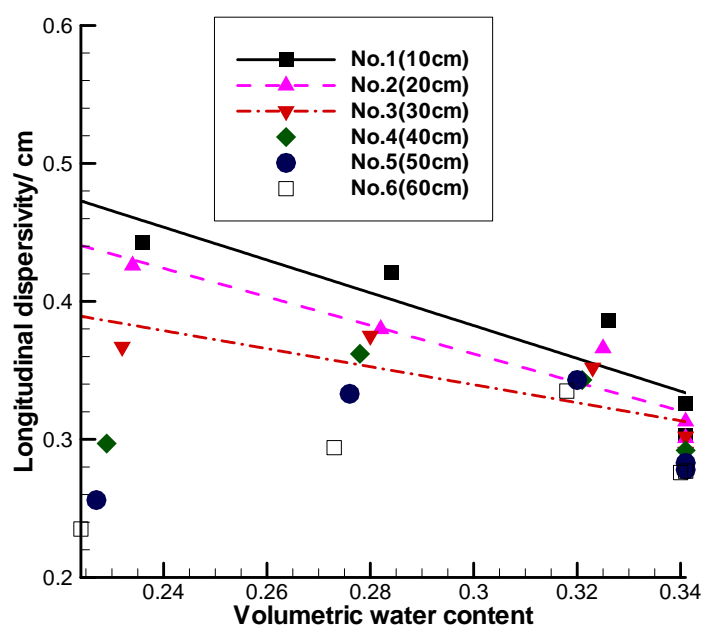

図-7＼cjkstart体積含水率に対する縱方向分散長

ここでCは物質濃度, $u(>0)$ は間隙流速, $\theta$ は体積含水率, $t$ は時間, 縦方向分散係数 $D_{\mathrm{L}}=\alpha_{\mathrm{L}} u$ および横方向分散係数 $D_{\mathrm{T}}=\alpha_{\mathrm{T}} u$ である. $\alpha_{\mathrm{L}}$ は縦方向分散長， $\alpha_{\mathrm{T}}$ は横方向分散長で ある. なお時空間にわたって体積含水率が変化しなけれ ば，結局次式のようになる.

$$
\frac{\partial C}{\partial t}+u \frac{\partial C}{\partial x}=D_{\mathrm{L}} \frac{\partial^{2} C}{\partial x^{2}}+D_{\mathrm{T}} \frac{\partial^{2} C}{\partial y^{2}}
$$

この基礎式に対して，帯水層がxyの正負の両方向に無限 遠まで広がっていると仮定し， $C_{0}$ の濃度のトレーサーを 時刻 $t=0$, 場所 $x=0, y=0$ において瞬間投入した場合の解析 解は次式で与えられる.

$$
C=\frac{C_{0}}{4 \pi u \sqrt{\alpha_{\mathrm{L}} \alpha_{\mathrm{T}} t}} \exp \left(-\frac{(x-u t)^{2}}{4 \alpha_{\mathrm{L}} u t}-\frac{y^{2}}{4 \alpha_{\mathrm{T}} u t}\right)
$$

この解析解が実測值によくあうように $\alpha_{\mathrm{L}}$ と $\alpha_{\mathrm{T}}$ を非線形最 小自乗法により求めた．なお，上下流で水位差をつけて いるので，厳密には空間的に体積含水率が一定とは言え ないが，式(2)を基礎式とすることの妥当性は，次のよう に考えた. 図-5に，断面平均の体積含水率を観測点ごと にプロットして，すべての数值計算ケースについて示す。 上流側から下流側へ向かい，水位が低下寸るため, 確か に水分量は低くなっていることが分かるが，その減少量

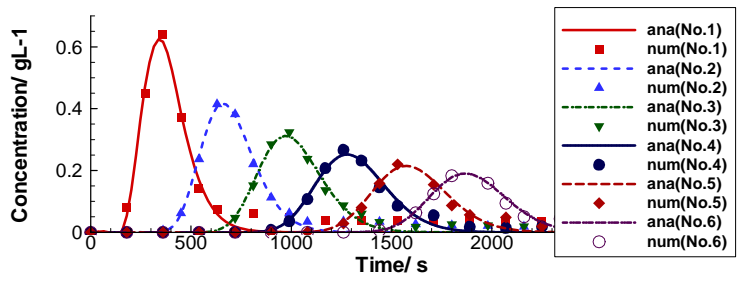

図-6 数值計算によるトレ一サーの分散と解析解のフィッ ティング (Ex2)

はわずかであり，それぞれの数值計算ケースにおいて， 体積含水率はほぼ一定であると考える.

図-6に，一例として，Ex2の場合の数值計算による卜 レーサーの分散と解析解のフィッティング結果について 示している. 上流側から順に濃度が立ち上がりピークに 到達することとピーク濃度が注入点から遠方になるに従 い低減することが分かり，正しく計算されたことが窥え る.

\section{4. 分散長評価結果と考察}

図-7には，トレーサー注入孔からの距離毎にまとめた 体積含水率と評価された縦方向分散長をプロットしてい る.プロットした值は，観測点のみで評価した值であり， その点までの值は考慮していない，実験了のデータをま とめた場合より，バラツキは少なくなった．トレーサー 注入位置からの距離が，10〜30 cmの場合に，近似曲線 をプロットした．その傾向は，体積含水率が大きくなる と, 縦方向分散長が小さくなる傾向にあり, これらは従 来の知見とも相違せず(例えばToride et al.の実験結果²), 実験結果とも整合する結果が得られた．間隙空気の増加 が，水とそこに溶存している物質の移動を妨げる確率を 高め, 移動しやすい部分と移動しにくい部分の差が大き くなることがその一因と考えられる．体積含水率が大き くなると，巨視的に評価しているので，完全には一致し ないものの, 数值計算で与えた縦方向の微視的分散長 $(0.216 \mathrm{~cm})$ に近づいている. トレーサー注入位置から40 ６0 cmの場合は，体積含水率が低いケースで分散長が 特に小さく評価された. この原因は, 水分量の低い浸透 水槽上部におけるトレーサーの輸送が極端に遅延し，観 測点で断面平均された破過曲線が, 到達の早いものと遅

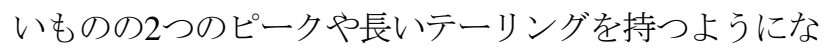
り, 先行しているピークへのフィッティングにより評価 されてしまったためと考えられる。一例としてEx1の観 測点No.6 (トレーサー注入点から60 cm)における破過曲 線を図-8に示す. 今回の解析解による評価は，数值解の 2 つめのピークとテーリングをとらえきれていない. こ のような場合への評価方法は, 今後検討しなければなら 


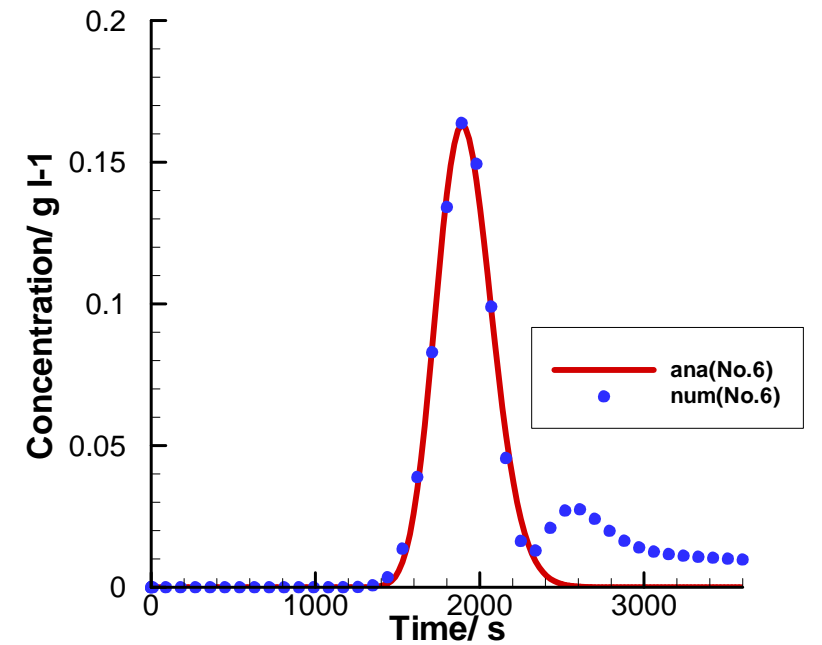

図-8 Ex1の観測点No. 6での破過曲線 (ana:解析解, num: 数值解)

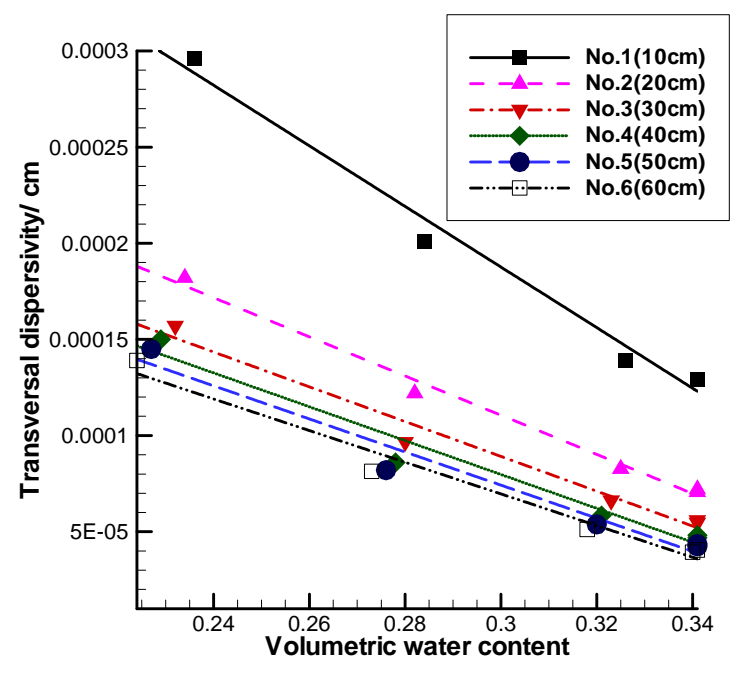

図-9＼cjkstart体積含水率に対する横方向分散長

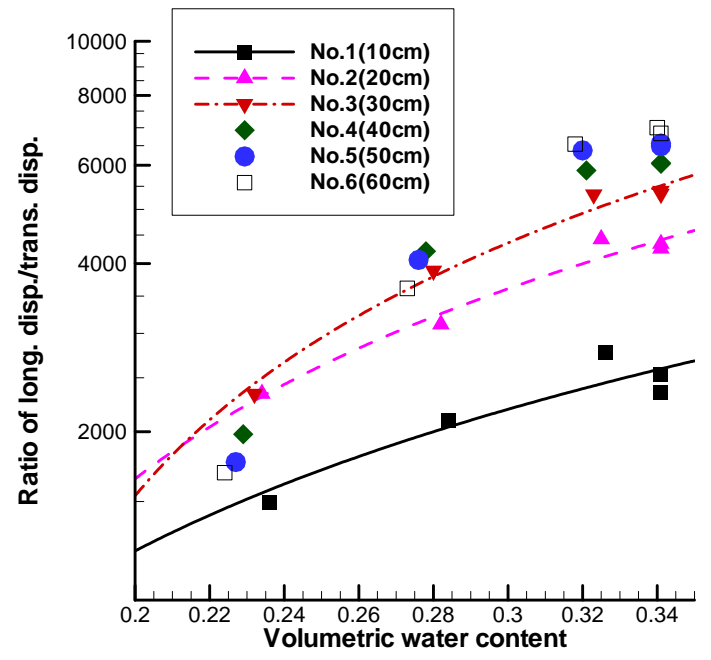

図-10 体積含水率に対する縦方向分散長と横方向分散長の比
ない.ピークが分かれるような場合でも，それらを包括 する曲線の裾幅は，水分量の上昇により狭くなる傾向に あり，10〜30 cmにおける水分量に対する分散長の関係 と一致する.

図-9には，トレーサー注入孔からの距離毎にまとめた 体積含水率と横方向分散長および近似曲線をプロットし ている．実験 ${ }^{3)}$ と同様，全体的にかなり小さく評価され， 縦方向分散長と同様，土壌水分量が少なくなると横方向 分散長が大きくなる傾向が確認できた.

図-10には，トレーサー注入孔からの距離毎にまとめ た縦方向分散長と横方向分散長の比および近似曲線をプ ロットしている。実験 ${ }^{3)}$ と同様，横方向の分散長が小さ く評価された．実験では，横方向分散長/縦方向分散長 の值は，1/100～1/1000の範囲に分布したが，今回の数值 計算によると，1/1000～1/6000の範囲となり，縦方向が 横方向に比べ，より大きくなるような結果となった。 ま

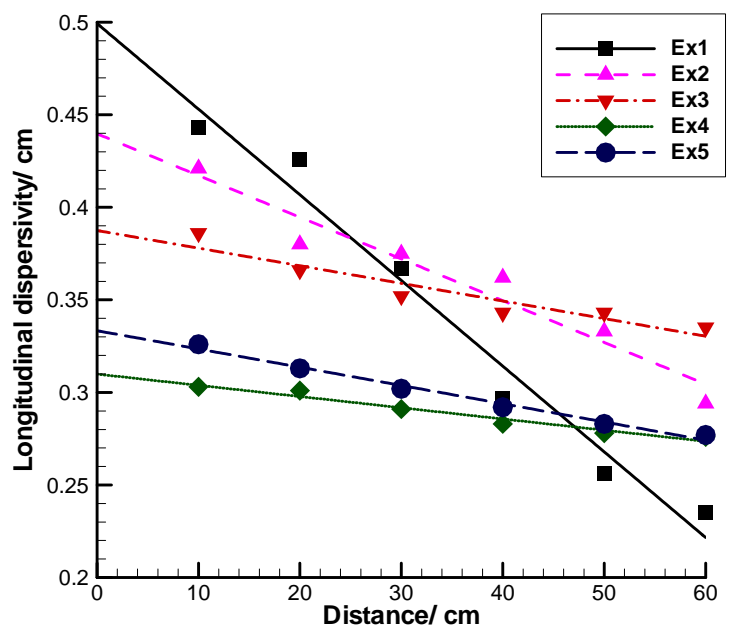

図-11 流下距離に対する縦方向分散長

た体積含水率が大きくなると横方向に対する縦方向の分 散長の比も大きくなる傾向にある. これは実験結果 ${ }^{3)}$ と も整合する結果であり, 水分量が多いと, 縦方向の輸送 がより促進されることを示している.

図-11には，トレーサー注入点からの距離に対する縦 方向分散長とその近似曲線をプロットしている. すべて のケースで，流下距離に応じて縦方向分散長は小さくな る傾向の存在が示唆された.この低下傾向の勾配は不飽 和度の大きいケースであるEx1で特に大きい. これは図一 8を示して説明したように，水分量が低いケース(特に Ex1)では，解析解により正しく評価できず，分散長を特 に小さく求めてしまったことが原因である.したがって 低下傾向の勾配は，本来ここまで大きくはならないと考 えられる. Ex3からの飽和度の大きいケースでは，低下 傾向の勾配は大きくなく，この浸透水槽程度の範囲では， ほぼ一定であるとみてよいと考えられる．実験結果3か 


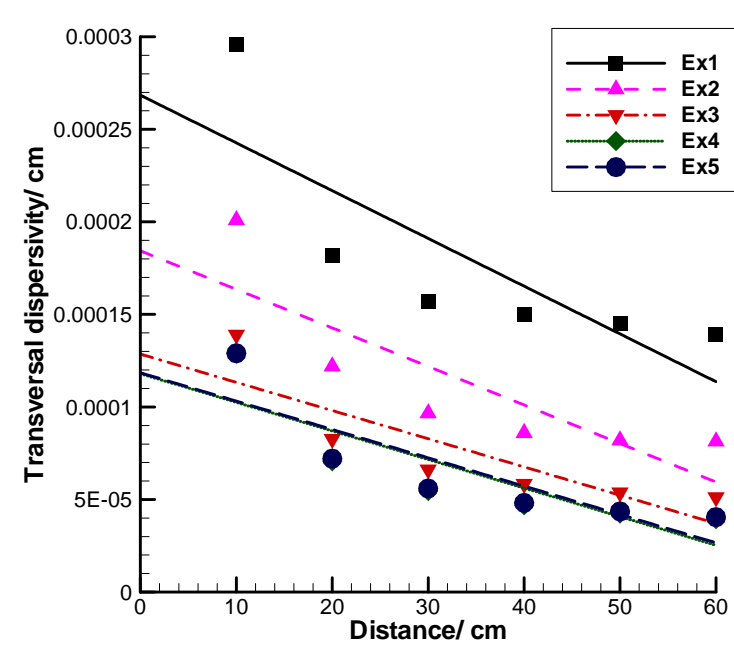

図-12 流下距離に対する横方向分散長

らは，距離に対して低下傾向もあるが，全体的な傾向は 増加傾向で，スケール効果を示したと結論づけたが，今 回の数值計算では, その傾向は見られなかった.

図-12には，トレーサー注入点からの距離に対する横 方向分散長とその近似曲線をプロットしている. 距離に 応じて小さくなる傾向が見られた．トレーサー注入点か ら30 cm以降は一定值に収束していくように見え，この 傾向は実験結果3)とも一致した。実験3)では, トレーサー をシリンジを用いて瞬間的に注入したため，注入直後は 注入点で同心円状にトレーサープリュームが拡がった.

今回の数值計算でも, 同様の状況からの計算を実施した. そのため, 初期の横方向への拡がりが大きめに生じ，そ の後距離を経て落ち着いたと考えられる.

図-13には，トレーサー注入点からの距離に対する縦 方向分散長と横方向分散長の比とその近似曲線をプロッ トしている．飽和度の低いEx1とEx2以外のケースでは， ほぼ一様に距離に応じて縦方向と横方向の分散長比が大 きくなる傾向にある，飽和度が低い場合は，水分量が低 く縦方向への広がりがあまり進まなかったからと考えら れる.

\section{5. おわりに}

本研究では, 中川ら ${ }^{3)}$ が実施した, 水平浸透水槽を用 いた不飽和状態の流れ場における，室内トレーサ一試験 に対して, 数値計算により再度, 分散長の評価を行うこ とを試みた。分散長の評価は，実験了) と同様，実測值へ の非線形最小自乗法による解析解のあてはめにより行っ た. その結果, 縦方向および横方向分散長の土壌水分量 依存性を確認した。 実験了) と同様に，水分量が低下寸る と縦方向分散長が大きくなる傾向にあることを確認し，

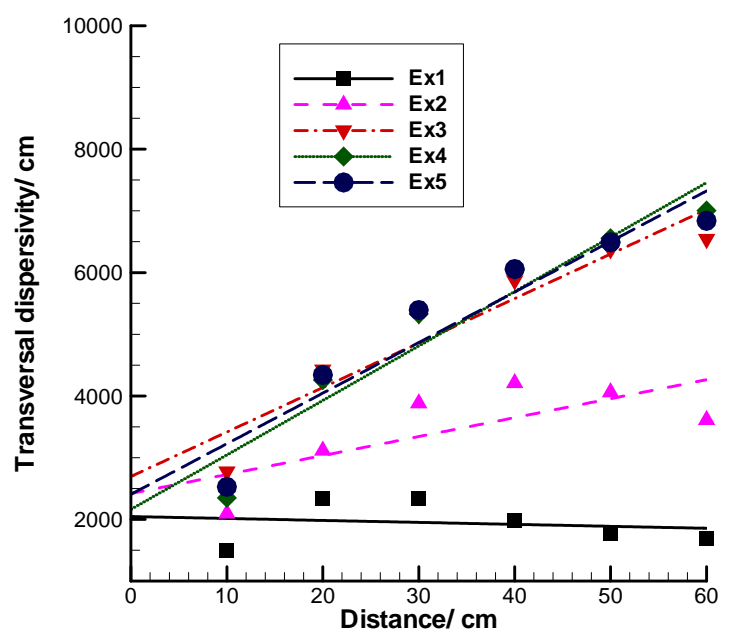

図-13 流下距離にこ対する縦方向分散長と横方向分散長の比

そのメカニズムは，間隙空気の増加が，水とそこに溶存 している物質の移動を妨げる確率を高め, 移動しやすい 部分と移動しにくい部分の差が大きくなることであると 考えられる. また今回の数值計算結果からは, 横方向分 散長/縦方向分散長は1/1000～1/6000 に分布し, 実験結 果3)よりもより縦方向の分散が大きい結果となった. 実 験結果3)からは, 流下距離に対寸る不飽和分散長の増加 傾向があることが示唆されたが，本研究の数值計算結果 からは，その傾向は見られず，わずかな低下傾向であり， むしろ一定であるようであった. 対象とした浸透水槽程 度の規模では, 不飽和の分散長におけるスケール効果は 見出されないと考えられる.

\section{参考文献}

1) 坂本 康, 穴水大介, 平山公明, 熱田洋一, 西田 継: 表層不 飽和土㙥層での溶質移動パラメータの空間分布特性と観測ス ケールの影響,水工学論文集,Vol.47, pp.301-306, 2003.

2) Toride, N., Inoue, M. and Leij, F.J.: Hydrodynamic dispersion in an unsaturated dune sand, Soil Sci. Soc. Am. J., Vol.67, pp.703-712, 2003.

3) 中川 啓, 中川原尚子, 齋藤雅彦 : 水平浸透水槽を用いた卜 レーサー試験による不飽和分散長の評価, 水工学論文 集,Vol.54,pp.595-600, 2010.

4) Simunek, J., van Genuchten, Th. and Sejna, M.: The HYDRUS Software Package for Simulating the Two- and Three-Dimensional Movement of Water, Heat, and Multiple Solutes in VariablySaturated Media Technical Manual Version 1.0, 2006.

5) Bear, J.: Dynamics of Fluids in Porous Media, American Elsevier, 1972.

6) Kinzelbach, W.: パソコンによる地下水解析, 上田年比古監訳, 森北出版, pp.181-182, 1990.

(2011. 9. 30受付) 